\title{
The Prevalence of Metabolic Syndrome in Ethiopian Population: A Systematic Review and Meta-analysis
}

\author{
Sintayehu Ambachew (D, ${ }^{1}$ Aklilu Endalamaw, ${ }^{2}$ Abebaw Worede, ${ }^{1}$ Yalewayker Tegegne, ${ }^{3}$ \\ Mulugeta Melku, ${ }^{4}$ and Belete Biadgo ${ }^{1}$ \\ ${ }^{1}$ Department of Clinical Chemistry, School of Biomedical and Laboratory Sciences, College of Medicine and Health Sciences, \\ University of Gondar, Gondar, Ethiopia \\ ${ }^{2}$ Departement of Pediatrics and Child Health Nursing, School of Nursing, College of Medicine and Health Sciences, \\ Bahir Dar University, Bahir Dar, Ethiopia \\ ${ }^{3}$ Department of Parasitology, School of Biomedical and Laboratory Sciences, College of Medicine and Health Sciences, \\ University of Gondar, Gondar, Ethiopia \\ ${ }^{4}$ Department of Hematology and Immunohematology, School of Biomedical and Laboratory Sciences, \\ College of Medicine and Health Sciences, University of Gondar, Gondar, Ethiopia
}

Correspondence should be addressed to Sintayehu Ambachew; sinte.ambachew@gmail.com

Received 15 May 2020; Revised 5 November 2020; Accepted 30 November 2020; Published 16 December 2020

Academic Editor: Mario Musella

Copyright (C) 2020 Sintayehu Ambachew et al. This is an open access article distributed under the Creative Commons Attribution License, which permits unrestricted use, distribution, and reproduction in any medium, provided the original work is properly cited.

Background. The metabolic syndrome is a clustering of hyperglycemia/insulin resistance, hypertension, dyslipidemia, and obesity which are risk factors for cardiovascular disease, type 2 diabetes and stroke, and all-cause mortality. The burden of metabolic syndrome is emerging alarmingly in low- and middle-income countries such as Ethiopia; however, there is lack of comprehensive estimation. This study aimed to determine the pooled prevalence of metabolic syndrome in Ethiopia. Methods. This systematic review and meta-analysis included original articles of observational studies published in the English language. Searches were carried out in PubMed, Google Scholar, and Africa Journals from conception to August 2020. A random-effects model was used to estimate the pooled prevalence of metabolic syndrome in Ethiopia. Heterogeneity was assessed using the $I^{2}$ statistic. Subgroup analysis was also conducted based on sex/gender and study subjects. Egger's test was used to assess publication bias. Results. Electronic and gray literature search retrieved 942 potentially relevant papers. After removing duplicates and screening with eligibility criteria, twenty-eight cross-sectional studies were included in this meta-analysis. The pooled prevalence of metabolic syndrome in Ethiopia was found to be $34.89 \%$ (95\% CI: 26.77, 43.01) and 27.92\% (95\% CI: 21.32, 34.51) by using NCEP/ATP III and IDF criteria, respectively. The weighted pooled prevalence of metabolic syndrome was higher in females 36.74\% (95\% CI: $20.72,52.75)$ and $34.09 \%$ (95\% CI: $26.68,41.50)$ compared to males $22.22 \%$ (95\% CI: $14.89,29.56)$ and $24.82 \%$ (95\% CI: 18.34 , 31.31) by using IDF and NCEP/ATP III criteria, respectively. Subgroup analysis based on the study subjects using NCEP/ATP III showed that the weighted pooled prevalence was $63.78 \%(95 \%$ CI: $56.17,71.40)$ ), 44.55\% (95\% CI: 30.71, 52.38), 23.09\% (95\% CI: 19.74, 26.45), 20.83\% (95\% CI: 18.64, 23.01), and 18.45\% (95\% CI: 13.89, 23.01) among type 2 diabetes patients, hypertensive patients, psychiatric patients, HIV patients on HAART, and working adults, respectively. The most frequent metabolic syndrome components were low HDL-C 51.0\% (95\% CI: 42.4, 59.7) and hypertriglyceridemia 39.7\% (95\% CI: 32.8, 46.6). Conclusions. The findings revealed an emerging high prevalence of metabolic syndrome in Ethiopia. Therefore, early intervention is required for the primary prevention of the occurrence of metabolic syndrome and the further reduction of the morbidity and mortality related to it. 


\section{Background}

Metabolic syndrome (MetS) is a cluster of interrelated risk factors that have been associated with cardiovascular disease (CVD), stroke, diabetes mellitus, and other comorbidities $[1,2]$. Insulin resistance, obesity, dyslipidemia, and hypertension are considered to be the primary components of MetS [3, 4]. The worldwide prevalence of MetS and noncommunicable chronic diseases in the adult population is on the rise [5]. It has been estimated that the prevalence of MetS ranges $20-25 \%$ of the adult population globally [6]. The epidemiologic nature of MetS is also emerging alarmingly and being common in Africa in contrast to the earlier trend of being considered rare. The increase in the prevalence of MetS in Africa is thought to be due to divergence from traditional African to Western lifestyles [7]. High prevalence of MetS has been reported in some sub-Saharan Africa countries such as in Morocco (16.3\%) and South Africa (33.5\%) [8].

The individual with MetS has 2-3 times higher chance of developing stroke and CVD than without MetS $[9,10]$. It has also a six-fold greater risk of developing type 2 diabetes (T2DM) [11]. T2DM has become one of the major causes of premature illness and death, mainly through the increased risk of CVD disease [12]. MetS is also associated with other comorbidities such as cancer, nonalcoholic fatty liver disease, and other reproductive disorder [13-15]. It is also suggested that mortality due to MetS is more than twice that without the syndrome [16]. The prevalence of MetS varies across different populations. MetS appear to be more common in the presence of comorbidities such as diabetes mellitus, hypertension, and HIV infection than their counterparts. Around $85 \%$ of those with diabetes have MetS in the United States in contrast to $25 \%$ of working adults in Europe and Latin America [17, 18]. Likewise, the high prevalence of HIV infection in developing countries and concomitant antiretroviral therapy is also associated with the rise of MetS [19]. Todowede O. O. et al. have reported in a meta-analysis that MetS prevalence among people living with HIV was $21.5 \%$ in contrast to uninfected $12.0 \%$ [20]. MetS rates are rising in developing countries in an epidemic situation [7]. For instance, in Ethiopia, the prevalence of MetS among T2DM, hypertensive, and HIV patients is estimated to be high [21-23]. The pathogenesis of the MetS is multidirectional, but obesity-induced insulin resistance is the major pathway for the occurrence of MetS [24]. Similarly, increased risk of MetS and its components is attributed to antiretroviral therapy and other related factors [25]. Sociodemographic factors, behavioral factors, stress, family history of disease, and some anthropometric measurements have been reported as associated factors of MetS in different literatures [26-28]. For instance, a study conducted among Malaysian population has showed that increasing age and low physical activity have been associated with increased odds of MetS [29].

Due to the dramatic increase in urbanization, smoking, severe stress-related problems of poverty, nutrition transition, reduced physical activity, and over nutrition increasing on top of the already high prevalence of undernutrition, sub-
Saharan Africa is facing a rapid escalation of MetS and noncommunicable chronic diseases and associated mortality [30-32].

In Ethiopia, several studies were conducted to assess the prevalence of MetS among different study subjects having great disparity and inconsistent findings. However, there is lack of comprehensive estimation of MetS in Ethiopia. Hence, this systematic review aimed to determine the pooled prevalence of MetS among the Ethiopian population of various study subjects. This will provide the necessary information for policymakers, clinicians, and concerned stakeholders in the country to provide an appropriate strategy and intervene in the control, prevention, and management of MetS.

\section{Methods}

2.1. Protocol and Search Strategy. This systematic review and meta-analysis was reported according to the Preferred Reporting Items for Systematic Reviews and Meta-Analyses statement guideline. The study protocol was registered in the PROSPERO International Prospective Register of Systematic Reviews (CRD42018090944) [33]. An inclusive literature search was conducted to identify studies about the prevalence of MetS reported among the Ethiopian population of various study subjects. Both electronic and gray literature searches were carried out systematically. PubMed, African journal of Medline, and Google Scholar were used to retrieve data. The search terms were used separately and in combination using Boolean operators like "OR" or "AND." An example of keywords used in PubMed to select relevant studies was as follows: [((Metabolic syndrome [Title/Abstract]) OR (MS [Title/Abstract]) OR (MetS [Title/Abstract]) OR (Insulin resistance syndrome [Title/Abstract]) OR (syndrome $\mathrm{X}$ [Title/Abstract]) OR (MtS [Title/Abstract])) AND (Ethiopia [Title/Abstract])]. Moreover, a snowball search was used to search the citation lists of included studies. The search incorporated studies recorded up to the $30^{\text {th }}$ of August 2020. The software EndNote version X7 (Thomson Reuters, New York, NY) was used to manage references and remove duplicated references.

2.2. Design. This systematic review and meta-analysis was conducted to estimate the pooled prevalence of MetS based on the International Diabetes Federation [6] and National Cholesterol Education Program-Adult Treatment Panel III (NCEP/ATP III) criteria [34] (Table 1) among different study subjects in Ethiopia.

2.3. Exclusion and Inclusion Criteria. Observational studies (all of them were cross-sectional studies) that described the prevalence of MetS among the indigenous Ethiopian population were included. All included studies were original research articles published in English and contained the minimum information (study participants and number of MetS cases). Moreover, studies in which MetS has been reported using (i) IDF criteria and/or (ii) NCEP/ATPIII were included. The full text of studies meeting these criteria 
TABle 1: Definitions of metabolic syndrome by using NCEP/ATPIII and IDF criteria.

\begin{tabular}{|c|c|c|}
\hline & NCEP/ATPIII & IDF \\
\hline Absolutely required & None & $\begin{array}{c}\text { Central obesity (waist circumference } \$ \text { ): } 94 \mathrm{~cm}(\mathrm{M}) \\
\text { and } \geq 80 \mathrm{~cm}(\mathrm{~F})\end{array}$ \\
\hline Criteria & Any three of the five criteria below & Obesity, plus two of the four criteria below \\
\hline Obesity & $\begin{array}{c}\text { Waist circumference: }>40 \text { inches }(\mathrm{M}) \text { and }>35 \\
\text { inches }(\mathrm{F})\end{array}$ & Central obesity already required \\
\hline Hyperglycemia & Fasting glucose $>100 \mathrm{mg} / \mathrm{dl}$ or $\mathrm{Rx}$ & Fasting glucose $>100 \mathrm{mg} / \mathrm{dl}$ \\
\hline Dyslipidemia & $\mathrm{TG}>150 \mathrm{mg} / \mathrm{dl}$ or $\mathrm{Rx}$ & $\mathrm{TG}>150 \mathrm{mg} / \mathrm{dl}$ or $\mathrm{Rx}$ \\
\hline $\begin{array}{l}\text { Dyslipidemia (second, separate } \\
\text { criteria) }\end{array}$ & $\begin{array}{c}\text { HDL-C: }<40 \mathrm{mg} / \mathrm{dl}(\mathrm{M}) \text { and }<50 \mathrm{mg} / \mathrm{dl}(\mathrm{F}) \text { or } \\
\mathrm{Rx}\end{array}$ & HDL-C: $<40 \mathrm{mg} / \mathrm{dl}(\mathrm{M})$ and $<50 \mathrm{mg} / \mathrm{dl}(\mathrm{F})$ or $\mathrm{Rx}$ \\
\hline Hypertension & $\begin{array}{c}>130 \mathrm{mmHg} \text { systolic or }>85 \mathrm{mmHg} \text { diastolic } \\
\text { or } \mathrm{Rx}\end{array}$ & $>130 \mathrm{mmHg}$ systolic or $>85 \mathrm{mmHg}$ diastolic or $\mathrm{Rx}$ \\
\hline
\end{tabular}

Rx, pharmacologic treatment; NCEP/ATPIII, National Cholesterol Education Program-Adult Treatment Panel III; IDF, International Diabetes Federation; TG, triglyceride; HDL-C, high-density lipoprotein cholesterol.

was retrieved and screened to determine its eligibility. Whereas studies in which MetS was described on other than the Ethiopian population, nonoriginal research (such as review, editorial, and a letter or commentary), and unknown/unclear methods of how MetS was diagnosed were not included.

2.4. Study Selection and Quality Assessment. Two reviewers (S.A. and M.M.) independently screened the titles and abstracts in the abovementioned databases to consider the articles in the full-text review. The quality of the studies was appraised using Joanna Brigg's Institute quality appraisal criteria (JBI) [35]. All selected articles were evaluated by using the JBI appraisal checklist. Studies that got 50\% and above on the quality scale were considered to have good quality (Table 2).

2.5. Data Extraction. To collect relevant data, a data extraction tool was developed, and one reviewer (SA) was responsible for the extraction of data from the included studies. Information regarding authors, year of publication, the study population, type of study/study design, number of participants, gender, diagnostic criteria for defining Mets, region, study area, sampling techniques, and the prevalence of MetS in each study were collected. The extracted data were checked by the second reviewer (AE) for its accuracy and consistency. A third reviewer (YT) was also engaged where necessary.

2.6. Data Analysis. The extracted data were entered into Microsoft Excel and analyzed using STATA version 14 (StataCorp. 2009. Stata Statistical Software. College Station, TX: StataCorp LP). A random-effects model was used to obtain an overall summary estimate of the prevalence across studies. Point estimation with a confidence interval of $95 \%$ was used. Sensitivity analysis was conducted to assess the role of each study in the final result by excluding each study one by one. The presence of publication bias was assessed by using Egger's test. Trim and fill method analyses have been conducted to obtain a bias-adjusted effect estimate. Heterogeneity across studies was checked by Cochran's $Q$ statistic and $I^{2}$ statistics. Moreover, meta-regression has been conducted that represent linear predictions for the MetS prevalence as a function of published year. Subgroup analysis was performed based on sex/gender, and study subjects since there have unexplained significant heterogeneity.

\section{Result}

3.1. Characteristics of Included Studies. Out of 942 potential articles, 233 articles were found to be relevant to the topic of interest screened by title and abstract. Then, 115 were found to be eligible for full-text assessment. Of these full-text screened articles, 28 of them comprising 20652 study participants were found to be eligible for meta-analysis (Table 3). Figure 1 showed the results of the search and reasons for exclusion during the study selection process.

The prevalence of MetS was estimated based on the IDF and NCEP/ATPIII criteria among the Ethiopian population of various study subjects. Fourteen studies reported the prevalence of MetS based on both IDF and NCEP/ATPIII criteria [36-44, 48-50, 54, 56], seven studies based on NCEP/ATPIII criteria only [57-63], and again seven studies by IDF criteria only [ $45-47,51-53,55]$. Table 3 presents the characteristics and outcomes of the reviewed studies.

\subsection{Prevalence of MetS Using IDF and NCEP ATP III Criteria.} The random-effects model was applied since the heterogeneity index of the studies was significant. The pooled prevalence of metabolic syndrome in Ethiopia was found to be $34.89 \%$ (95\% CI: $26.77,43.01)$ and $27.92 \%$ (95\% CI: 21.32 , 34.51 ) by using NCEP/ATP III and IDF criteria, respectively. Subgroup analysis based on the study subjects using NCEP/ ATP III showed that the weighted pooled prevalence was 63.78\% (95\% CI: 56.17, 71.40), 44.55\% (95\% CI: 30.71, 52.38), 23.09\% (95\% CI: 19.74, 26.45), 20.83\% (95\% CI: 18.64, 23.01), and $18.45 \%$ (95\% CI: $13.89,23.01)$ among type 2 diabetes patients, hypertensive patients, psychiatric patients, HIV patients on highly active antiretroviral therapy (HAART), and working adults, respectively. Using IDF criteria, subgroup analysis based on the study subjects showed that the weighted pooled prevalence was 53.26\% (95\% CI: 50.37, 
TABLE 2: Methodological quality assessment of included studies using Joanna Brigg's Institute quality appraisal criteria scale (JBI).

\begin{tabular}{|c|c|c|c|c|c|c|c|c|}
\hline $\begin{array}{l}\text { Study [Ref.]/ } \\
\text { Year }\end{array}$ & $\begin{array}{c}\text { Was the sample } \\
\text { representative } \\
\text { of the target } \\
\text { population? }\end{array}$ & $\begin{array}{c}\text { Were study } \\
\text { participants } \\
\text { recruited in } \\
\quad \text { an } \\
\text { appropriate } \\
\text { way? }\end{array}$ & $\begin{array}{l}\text { Was the } \\
\text { sample } \\
\text { size } \\
\text { adequate? }\end{array}$ & $\begin{array}{l}\text { Were the } \\
\text { study } \\
\text { subjects } \\
\text { and setting } \\
\text { described } \\
\text { in detail? }\end{array}$ & $\begin{array}{l}\text { Was the data } \\
\text { analysis } \\
\text { conducted } \\
\text { with } \\
\text { sufficient } \\
\text { coverage of } \\
\text { the identified } \\
\text { sample? }\end{array}$ & $\begin{array}{l}\text { Were objective } \\
\text { standard } \\
\text { criteria used for } \\
\text { measurement } \\
\text { of the } \\
\text { condition? }\end{array}$ & $\begin{array}{l}\text { Was the } \\
\text { condition } \\
\text { measured } \\
\text { reliably? }\end{array}$ & $\begin{array}{l}\text { Are all the } \\
\text { important } \\
\text { confounding } \\
\text { factors/ } \\
\text { subgroups/ } \\
\text { differences } \\
\text { identified and } \\
\text { accounted for? }\end{array}$ \\
\hline $\begin{array}{l}\text { Mossie et al. } \\
{[36] / 2016}\end{array}$ & Yes & Yes & Yes & Yes & Yes & Yes & Yes & Yes \\
\hline $\begin{array}{l}\text { Tachebele et al. } \\
{[37] / 2014}\end{array}$ & Yes & Yes & Yes & Yes & Yes & Yes & Yes & Yes \\
\hline $\begin{array}{l}\text { Bosho et al. } \\
\text { [38]/2018 }\end{array}$ & Yes & Yes & Yes & Yes & Yes & Yes & Yes & Yes \\
\hline $\begin{array}{l}\text { Hirigo et al. } \\
{[39] / 2016}\end{array}$ & Yes & Yes & Yes & Yes & Yes & Yes & Yes & Yes \\
\hline $\begin{array}{l}\text { Tran et al. [40]/ } \\
2011\end{array}$ & Yes & Yes & Yes & Yes & Yes & Not clear & Yes & Yes \\
\hline $\begin{array}{l}\text { Tesfaye et al. } \\
{[41] / 2014}\end{array}$ & Yes & Yes & Yes & Yes & Yes & Yes & Yes & Yes \\
\hline $\begin{array}{l}\text { Biadgo et al. } \\
\text { [42]/2018 }\end{array}$ & Yes & Yes & Yes & Yes & Yes & Yes & Yes & Yes \\
\hline $\begin{array}{l}\text { Birarra et al. } \\
{[43] / 2018}\end{array}$ & Yes & Yes & Yes & Yes & Yes & Yes & Yes & Yes \\
\hline $\begin{array}{l}\text { Solomon et al. } \\
{[44] / 2020}\end{array}$ & Yes & Not clear & Yes & Yes & Yes & Yes & Yes & Yes \\
\hline $\begin{array}{l}\text { Gebremeskel } \\
\text { et al. [45]/2019 }\end{array}$ & Yes & Yes & Yes & Yes & Yes & Yes & Yes & Yes \\
\hline $\begin{array}{l}\text { Bune et al. } \\
{[46] / 2020}\end{array}$ & Yes & Yes & Yes & Yes & Yes & Yes & Yes & Yes \\
\hline $\begin{array}{l}\text { Gebremariam } \\
\text { et al. [47]/2020 }\end{array}$ & Yes & Yes & Yes & Yes & Not clear & Yes & Yes & Yes \\
\hline $\begin{array}{l}\text { Asaye et al. } \\
{[48] / 2020}\end{array}$ & Yes & Yes & Yes & Yes & Yes & Yes & Yes & Yes \\
\hline $\begin{array}{l}\text { Wube et al. } \\
\text { [49]/2019 }\end{array}$ & Yes & Yes & Yes & Yes & Yes & Yes & Yes & Yes \\
\hline $\begin{array}{l}\text { Teshome et al. } \\
{[50] / 2020}\end{array}$ & Yes & Yes & Yes & Yes & Yes & Yes & Yes & Yes \\
\hline $\begin{array}{l}\text { Gebreyes et al. } \\
{[51] / 2018}\end{array}$ & Yes & Not clear & Yes & Yes & Yes & Not clear & Yes & Yes \\
\hline $\begin{array}{l}\text { Kerie et al. } \\
{[52] / 2019}\end{array}$ & Yes & Yes & Yes & Yes & Yes & Yes & Yes & Yes \\
\hline $\begin{array}{l}\text { Gebrehiwot } \\
\text { et al. [53]/2020 }\end{array}$ & Yes & Yes & Yes & Yes & Yes & Yes & Yes & Yes \\
\hline $\begin{array}{l}\text { Ataro et al. } \\
{[54] / 2020}\end{array}$ & Yes & Yes & Yes & Yes & Yes & Yes & Yes & Yes \\
\hline $\begin{array}{l}\text { Melak et al. } \\
{[55] / 2016}\end{array}$ & Yes & Yes & Yes & Yes & Yes & Yes & Yes & Not clear \\
\hline $\begin{array}{l}\text { Geto et al. } \\
{[56] / 2018}\end{array}$ & Yes & Yes & Yes & Yes & Yes & Yes & Yes & Yes \\
\hline
\end{tabular}

56.14), 39.30\% (95\% CI: 33.77, 44.83), 20.07\% (95\% CI: $24.49,31.65), 23.49 \%$ (95\% CI: $21.22,25.77$ ), and $17.89 \%$ (95\% CI: 10.04, 25.73) among type 2 diabetes patients, hypertensive patients, psychiatric patients, HIV patients on HAART, and working adults, respectively (Figures 2 and 3 ). The weighted pooled prevalence of metabolic syndrome was higher in females $36.74 \%$ (95\% CI: 20.72, 52.75) and 34.09\% (95\% CI: $26.68,41.50)$ compared to males $22.22 \%$ (95\% CI: $14.89,29.56)$ and $24.82 \%$ (95\% CI: $18.34,31.31)$ by using IDF and NCEP/ATP III criteria, respectively (Table 4).
Moreover, meta-regression has been conducted that characterize the linear predictions for the prevalence of MetS as a function of the increment of published year (Figures 4 and 5). An increasing trend in pooled prevalence of MetS is observed during the 2010-2020 time period in both IDF and NCEP/ATP III criteria.

3.3. Prevalence of the MetS Components. The prevalence of the individual components of MetS among the Ethiopian population varied considerably between studies (Table 5). In 
TABLE 3: Baseline characteristics and outcomes of the included studies $(n=28)$.

\begin{tabular}{|c|c|c|c|c|c|c|c|c|}
\hline Study [Ref.]/Year & Region & $\begin{array}{l}\text { Sampling } \\
\text { techniques }\end{array}$ & Study area & Study subjects & $\begin{array}{l}\text { Sample } \\
\text { Size, } n\end{array}$ & $\begin{array}{c}P \% \\
\text { (IDF) }\end{array}$ & $\begin{array}{l}P \% \text { (NCEP/ } \\
\text { ATPIII) }\end{array}$ & $\begin{array}{l}\text { Quality score by } \\
\text { JBI criteria }\end{array}$ \\
\hline $\begin{array}{l}\text { Berhan et al. [57]/ } \\
2012\end{array}$ & Oromia & MPSSS & Jimma & $\begin{array}{l}\text { HIV on } \\
\text { HAART }\end{array}$ & 313 & - & 21.1 & Good \\
\hline $\begin{array}{l}\text { Mossie et al. [36]/ } \\
2016\end{array}$ & Oromia & MPSSS & Jimma & Working adults & 1316 & 16.7 & 10.5 & Good \\
\hline $\begin{array}{l}\text { Tachebele et al. [37]/ } \\
2014\end{array}$ & Amhara & SRST & Gondar & Hypertensive & 300 & 39.3 & 40.7 & Good \\
\hline $\begin{array}{l}\text { Tadewos et al. [58]/ } \\
2018\end{array}$ & SNNP & SRST & Hawassa & Hypertensive & 238 & - & 48.7 & Good \\
\hline $\begin{array}{l}\text { Woyesa et al. [59]/ } \\
2017\end{array}$ & SNNP & SRST & Hawassa & T2DM patients & 314 & - & 70.1 & Good \\
\hline Bosho et al. [38]/2018 & Oromia & SRST & Jimma & $\begin{array}{l}\text { HIV on } \\
\text { HAART }\end{array}$ & 268 & 20.5 & 23.5 & Good \\
\hline $\begin{array}{l}\text { Hirigo et al. [39]/ } \\
2016\end{array}$ & SNNP & NA & Hawassa & $\begin{array}{l}\text { HIV on } \\
\text { HAART }\end{array}$ & 185 & 24.3 & 17.8 & Good \\
\hline Tran et al. [40]/2011 & $\begin{array}{l}\text { Addis } \\
\text { Ababa }\end{array}$ & MPSSS & $\begin{array}{l}\text { Addis } \\
\text { Ababa }\end{array}$ & Working adults & 1935 & 17.9 & 12.5 & Good \\
\hline Abda et al. [60]/2016 & Oromia & CST & Jimma & Working adults & 225 & - & 26 & Good \\
\hline $\begin{array}{l}\text { Tadewos et al. [61]/ } \\
2017\end{array}$ & SNNP & SRST & Hawassa & T2DM patients & 270 & - & 45.9 & Good \\
\hline $\begin{array}{l}\text { Tesfaye et al. [41]/ } \\
2014\end{array}$ & SNNP & SRST & Hawassa & $\begin{array}{l}\text { HIV on } \\
\text { HAART }\end{array}$ & 188 & 25 & 18.1 & Good \\
\hline $\begin{array}{l}\text { Biadgo et al. [42]/ } \\
2018\end{array}$ & Amhara & SRST & Gondar & T2DM patients & 159 & 53.5 & 66.7 & Good \\
\hline $\begin{array}{l}\text { Birarra et al. [43]/ } \\
2018\end{array}$ & Amhara & SRST & Gondar & T2DM patients & 256 & 57 & 70.3 & Good \\
\hline $\begin{array}{l}\text { Solomon et al. [44]/ } \\
2020\end{array}$ & $\begin{array}{l}\text { Addis } \\
\text { Ababa }\end{array}$ & NA & $\begin{array}{l}\text { Addis } \\
\text { Ababa }\end{array}$ & Working adults & 325 & 8.6 & 20.3 & Good \\
\hline $\begin{array}{l}\text { Gebremeskel et al. } \\
{[45] / 2019}\end{array}$ & Tigray & SRST & Mekele & T2DM patients & 419 & 51.1 & - & Good \\
\hline Bune et al. [46]/2020 & SNNP & SRST & $\begin{array}{l}\text { Gedeo } \\
\text { zone }\end{array}$ & $\begin{array}{l}\text { HIV on } \\
\text { HAART }\end{array}$ & 422 & 22 & - & Good \\
\hline $\begin{array}{l}\text { Gebremariam et al. } \\
{[47] / 2020}\end{array}$ & Tigray & Survey & Mekele & Working adults & 1380 & 40.7 & - & Good \\
\hline Asaye et al. [48]/2020 & Oromia & CST & Jimma & $\begin{array}{l}\text { Psychiatric } \\
\text { patients }\end{array}$ & 360 & 28.9 & 22.2 & Good \\
\hline Wube et al. [49]/2019 & SNNP & SRST & Hawassa & T2DM patients & 314 & 52.9 & 70.1 & Good \\
\hline $\begin{array}{l}\text { Teshome et al. [50]/ } \\
2020\end{array}$ & SNNP & SRST & Hawassa & $\begin{array}{l}\text { Psychiatric } \\
\text { patients }\end{array}$ & 245 & 26.9 & 24.5 & Good \\
\hline Zerga et al. [62]/2020 & Amhara & CST & Desie & T2DM patients & 330 & - & 59.4 & Good \\
\hline $\begin{array}{l}\text { Gebreyes et al. [51]/ } \\
2018\end{array}$ & All regions & NA & - & Working adults & 8673 & 4.8 & - & Good \\
\hline $\begin{array}{l}\text { KerieS et al. [52]/ } \\
2019\end{array}$ & SNNP & SRST & $\begin{array}{l}\text { Mizan- } \\
\text { Aman }\end{array}$ & Working adults & 534 & 9.6 & - & Good \\
\hline $\begin{array}{l}\text { Gebrehiwot et al. } \\
\text { [53]/2020 }\end{array}$ & Tigray & SRST & Mekele & Working adults & 266 & 21.8 & - & Good \\
\hline Ataro et al. [54]/2020 & $\begin{array}{l}\text { Eastern } \\
\text { Ethiopia }\end{array}$ & CST & Harar & $\begin{array}{l}\text { HIV on } \\
\text { HAART }\end{array}$ & 375 & 26.7 & 22.1 & Good \\
\hline $\begin{array}{l}\text { Cheneke et al. [63]/ } \\
2019\end{array}$ & $\begin{array}{l}\text { Eastern } \\
\text { Ethiopia }\end{array}$ & CST & Harar & Working adults & 365 & - & 27.7 & Good \\
\hline Melak et al. [55]/2016 & Amhara & SRST & Gondar & Working adults & 227 & 13.6 & - & Good \\
\hline Geto et al. [56]/2018 & $\begin{array}{l}\text { Addis } \\
\text { Ababa }\end{array}$ & CST & $\begin{array}{l}\text { Addis } \\
\text { Ababa }\end{array}$ & Working adults & 450 & 27.6 & 16.7 & Good \\
\hline
\end{tabular}

NCEP/ATPIII, National Cholesterol Education Program-Adult Treatment Panel III; IDF, International Diabetes Federation; T2DM, type 2 diabetes mellitus; MPSSS, multistage probabilistic stratified sampling strategy; SRST, simple/systematic random sampling technique; CST, consecutive sampling technique; SNNP, South Nation Nationality and People; HAART, highly active antiretroviral therapy; JBI, Joanna Brigg's Institute quality appraisal.

22 studies, the overall prevalence of individual components of MetS was reported, whereas in 6 studies, the prevalence of individual components of MetS was not reported. The overall weighted pooled prevalence by the component was as follows: abdominal obesity 35.85\% (95\% CI: 28.9, 42.8), hyperglycemia $26.4 \%$ (95\% CI: $20,32.8$ ), hypertension 


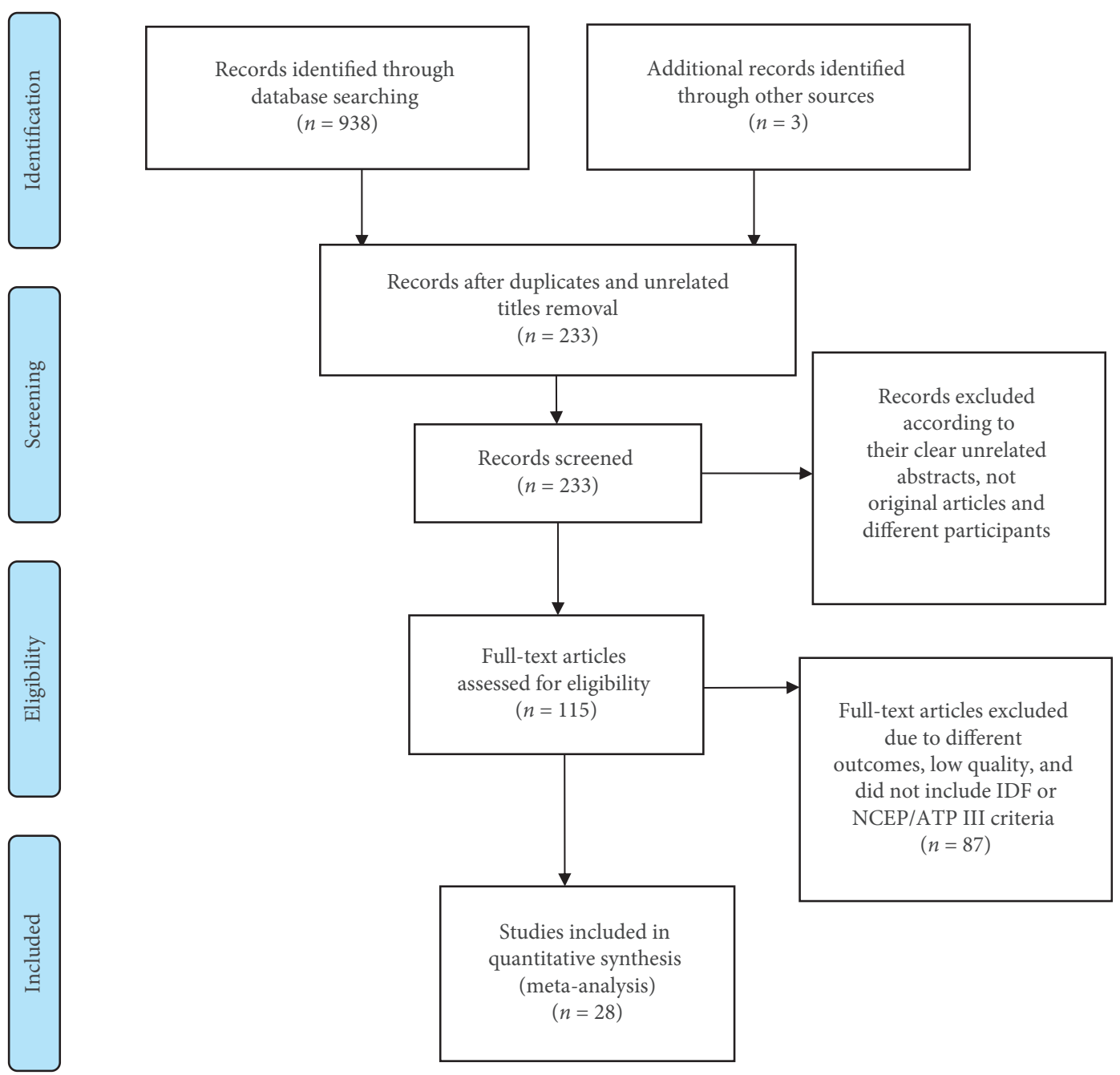

Figure 1: Flow diagram describing the steps of article inclusion to this systematic review.

27.87\% (95\% CI: 23.4, 32.2), hypertriglyceridemia $39.7 \%$ (95\% CI: 32.8, 46.6), and low HDL-C 51.0 (95\% CI: 42.4, 59.7) are summarized in Table 5.

3.4. Sensitivity Analysis. Sensitivity analysis was performed to assess the effect of each study on the pooled estimated prevalence of MetS by excluding each study step-by-step from the analysis process based on the two given diagnostic criteria (IDF and NCEP/ATP III). The result showed that excluded studies led to no significant changes in the shared estimation of the prevalence of MetS (Figures 6 and 7).

3.5. Publication Bias. The included studies were assessed for potential publication bias using Egger's test. Separate analyses using Egger's test based on IDF and NCEP/ATPIII criteria ( $p$ values were 0.001 and 0.001 , respectively) indicated the presence of publication bias. This indicates that the unpublished findings might have shown a larger magnitude of MetS. Adjusting the findings using the trim and fill method would provide a bias-adjusted effect estimate. Therefore, to do so, we have conducted trim and fill method analysis. A bias-adjusted effect estimate of MetS showed 9.67 $\%$ (95\% CI: $3.16,16.19)$ and $15.67 \%$ (95\% CI: 6.79, 24.55) by using IDF and NCEP/ATPIII criteria, respectively, assuming there are missing studies (Figures 8 and 9). However, there was somehow a difference compared with our previous results indicating minimally impacted by publication bias.

\section{Discussion}

The current systematic review provides evidence of an estimated pooled prevalence of MetS among various study subjects of the Ethiopian population. According to this review, the combined pooled prevalence of MetS was $34.89 \%$ (95\% CI: 26.77, 43.01) and 27.92\% (95\% CI: 21.32 , 34.51) by using NCEP/ATP III and IDF criteria, respectively. These results were slightly in line with the reports in Brazil (29.6\%) [64], Bangladesh (30\%) [65], Iran 31\% [66], and the United States (33\%) [67]. But the current pooled estimate was also higher than the prevalence estimated in Ghana (12.4\%) [68], Philippine (11.9\%) [69], and the global estimate (20-25\%) [6]. The findings were also lower as compared to Palestine (37.0\%) [70], the Greek population 


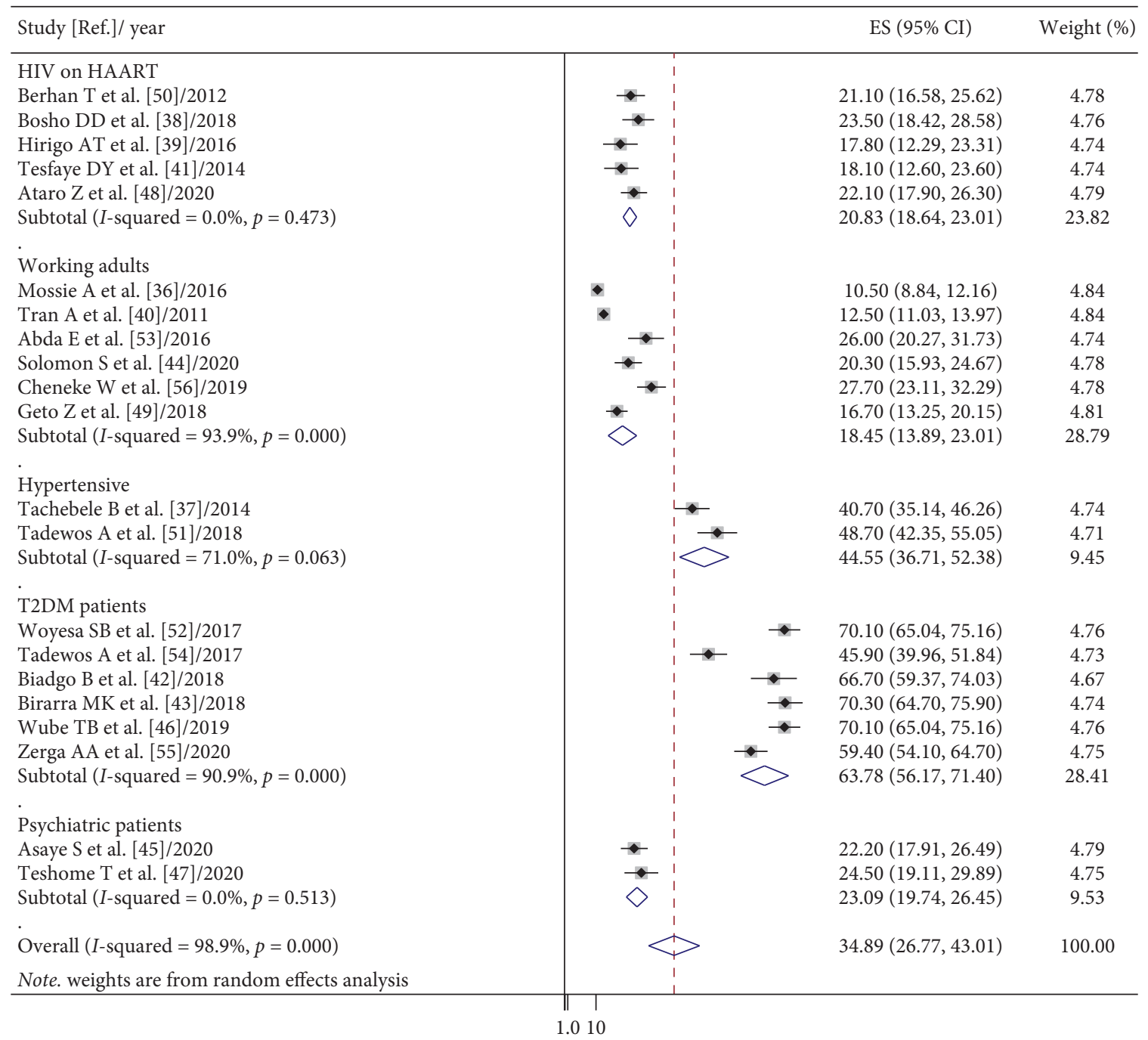

FIGURE 2: Forest plot of metabolic syndrome prevalence in Ethiopia based on NCEP/ATP III criteria.

(43.4\%) [71], and the population of Nepal (52.7\%) [72]. The variation in reports might be due to the difference in the underling important risk factors such as urbanization, westernization of lifestyle including unhealthy diet and physical inactivity [73], mental stress due to economic, social, and cultural factors [74], genetics, proinflammatory condition [75], intrauterine growth retardation, and over nutrition increasing on top of the already high prevalence of under nutrition [76].

The prevalence of MetS was high (34.89\%) when NCEP/ATPIII criteria was used compared to IDF criteria (27.92\%) in the current meta-analysis. These might be due to the relative flexibility of the NCEP/ATPIII in which central obesity is not the absolutely required criterion, unlike IDF [77]. However, it was different from a systematic review conducted among the Ghanaian population using these two criteria, NCEP/ATPIII (12.4\%) and IDF criteria (21.2\%) [68]. The discrepancy between the results of different studies could be attributed to the difference in abdominal obesity and waist circumference in different populations.
We observed high between-study heterogeneity across studies. In the subgroup analysis, the pooled prevalence of MetS using NCEP ATP III criteria was $63.78 \%$ among T2DM patients which was higher than the result of the rest of the study subjects, $18.45 \%, 20.83 \%, 23.09 \%$, and $44.55 \%$ among working adults, HIV patients on HAART, psychiatric patients, and hypertensive patients, respectively. This is also the same using IDF criteria. Though hyperglycemia is one of the components of Mets that increased its prevalence, insulin resistance-linked obesity might be the aggravated reason for the high prevalence of MetS among T2DM patients. In T2DM patients, particularly when glycemic control is poor, lipoprotein lipase activity is reduced [78]. The reduced lipoprotein lipase activity added with poor dieting and lack of regular exercise might be the reason for the higher prevalence of MetS among T2DM patients [79].

In line with other reviews $[66,80]$, the current metaanalysis demonstrated that the prevalence rate of MetS was higher in females compared to that in males. This has been shown in all the Middle Eastern countries, and the prevalence was much higher among women than men [81]. The 


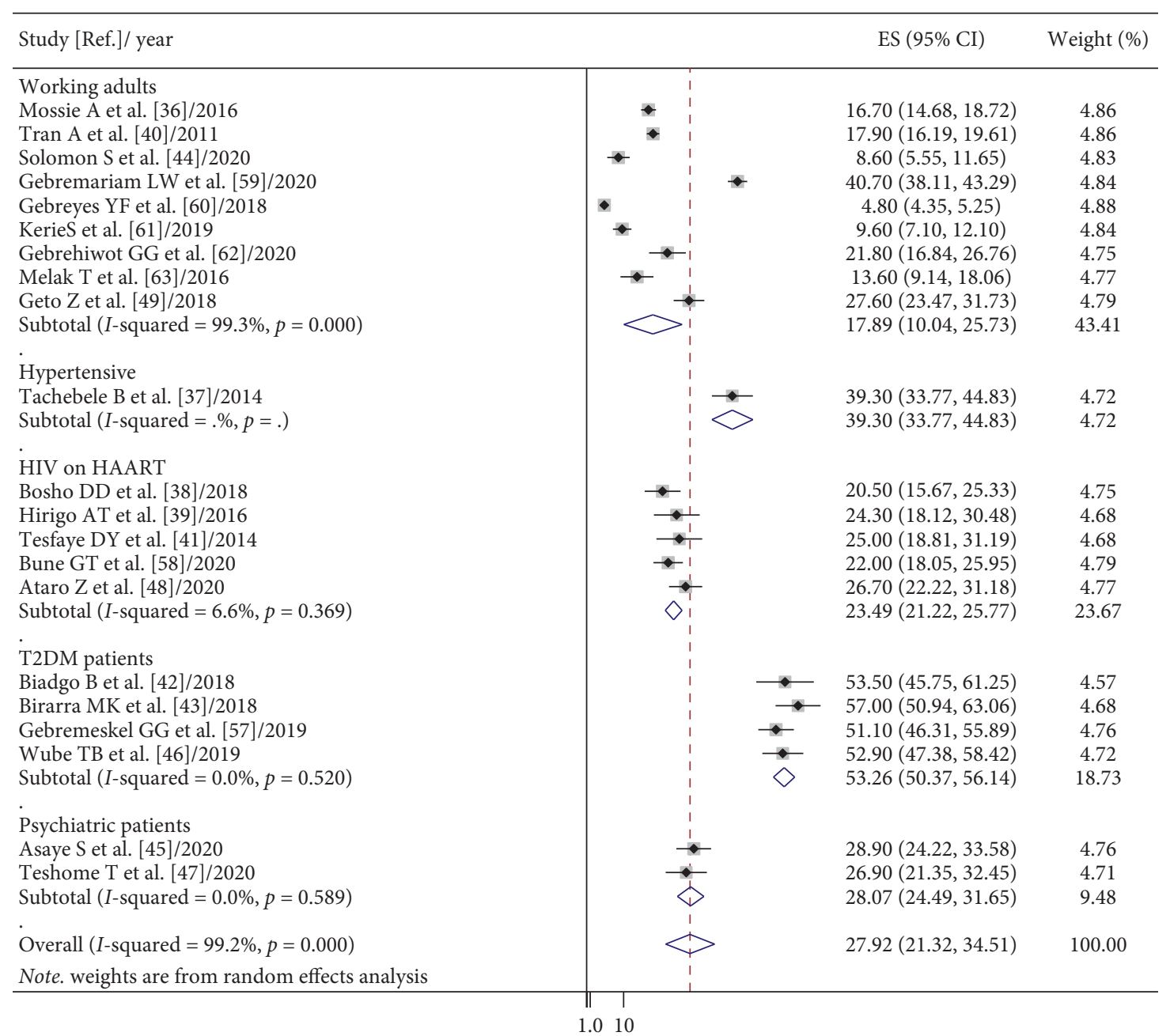

FIGURE 3: Forest plot of metabolic syndrome prevalence in Ethiopia based on IDF criteria.

Table 4: Pooled estimates of metabolic syndrome based on sex/gender.

\begin{tabular}{|c|c|c|c|c|c|c|}
\hline Study/Year & $\begin{array}{l}\text { Sample size } \\
\text { (male) }\end{array}$ & $\begin{array}{c}\text { Sample size } \\
\text { (female) }\end{array}$ & $\begin{array}{c}P \% \text { male by } \\
\text { NCEP/ATP III }\end{array}$ & $\begin{array}{l}P \% \text { female by } \\
\text { NCEP/ATP III }\end{array}$ & $\begin{array}{c}P \% \text { male } \\
\text { by IDF }\end{array}$ & $\begin{array}{c}P \% \text { female } \\
\text { by IDF }\end{array}$ \\
\hline Berhan et al. [57]/2012 & 109 & 204 & 17.4 & 23 & - & - \\
\hline Mossie et al. [36]/2016 & 620 & 696 & 6 & 14.5 & 11.1 & 21.7 \\
\hline Tachebele et al. [37]/2014 & 115 & 185 & 12 & 28.7 & 9.3 & 30.3 \\
\hline Tadewos et al. [58]/2018 & 105 & 133 & 37.9 & 62.1 & - & - \\
\hline Bosho et al. [38]/2018 & 57 & 211 & 21 & 24.2 & - & - \\
\hline Hirigo et al. [39]/2016 & 68 & 117 & 17.6 & 17.9 & 8.8 & 33.3 \\
\hline Tran et al. [40]/2011 & 1171 & 764 & 10 & 16.2 & - & - \\
\hline Abda et al. [60]/2016 & 106 & 119 & 16 & 35.3 & 14 & 24 \\
\hline Tadewos et al. [61]/2017 & 166 & 104 & 36.7 & 60.6 & - & - \\
\hline Tesfaye et al. [41]/2014 & 126 & 248 & 18.3 & 16.1 & 15.1 & 28.2 \\
\hline Biadgo et al. [42]/2018 & 64 & 95 & 56.3 & 73.7 & - & - \\
\hline Birarra et al. [43]/2018 & 113 & 143 & 33.9 & 66.1 & 27.4 & 72.6 \\
\hline Solomon et al. [44]/2020 & 155 & 170 & 18.1 & 22.4 & 1.9 & 14.7 \\
\hline Gebremeskel et al. [45]/2019 & 208 & 211 & - & - & 42.5 & 57.5 \\
\hline Gebremariam et al. [47]/2020 & 823 & 557 & - & - & 41.1 & 40.2 \\
\hline Asaye et al. [48]/2020 & 229 & 131 & 11.4 & 17.5 & - & - \\
\hline Wube et al. [49]/2019 & 211 & 103 & 69.7 & 70.9 & 32.7 & 94.2 \\
\hline Teshome et al. [50]/2020 & 143 & 102 & 46.7 & 53.3 & 47 & 53 \\
\hline Zerga et al. [62]/2020 & 170 & 160 & - & - & - & - \\
\hline
\end{tabular}


TABLE 4: Continued.

\begin{tabular}{|c|c|c|c|c|c|c|}
\hline Study/Year & $\begin{array}{l}\text { Sample size } \\
\text { (male) }\end{array}$ & $\begin{array}{l}\text { Sample size } \\
\text { (female) }\end{array}$ & $\begin{array}{l}\text { P\% male by } \\
\text { NCEP/ATP III }\end{array}$ & $\begin{array}{l}\text { P\% female by } \\
\text { NCEP/ATP III }\end{array}$ & $\begin{array}{l}P \% \text { male } \\
\text { by IDF }\end{array}$ & $\begin{array}{l}P \% \text { female } \\
\text { by IDF }\end{array}$ \\
\hline Gebreyes et al. [51]/2018 & 1306 & 7367 & - & - & 8.6 & 1.8 \\
\hline KerieS et al. [52]/2019 & 271 & 263 & 6.6 & 12.5 & - & - \\
\hline Gebrehiwot et al. [53]/2020 & 124 & 142 & - & - & 18.5 & 24.6 \\
\hline Cheneke et al. [63]/2019 & - & 365 & -202 & 27.7 & - & - \\
\hline Geto et al. [56]/2018 & 232 & 218 & 19.4 & 13.8 & 35.8 & 18.8 \\
\hline $\begin{array}{l}\text { Combined pooled estimate } \\
\text { (95\% CI: LCI, UCI) }\end{array}$ & $\begin{array}{c}24.82 \% \text { (95\% CI: } \\
18.34,31.31)\end{array}$ & $\begin{array}{c}34.09 \% \text { (95\% CI: } \\
26.68,41.50)\end{array}$ & $\begin{array}{c}22.22 \% \text { (95\% CI: } \\
14.89,29.56)\end{array}$ & $\begin{array}{c}36.74 \% \text { (95\% CI: } \\
20.72,52.75)\end{array}$ & & \\
\hline
\end{tabular}

NCEP/ATPIII, National Cholesterol Education Program-Adult Treatment Panel III; IDF, International Diabetes Federation; LCI, lower confidence interval; UCI, upper confidence interval.

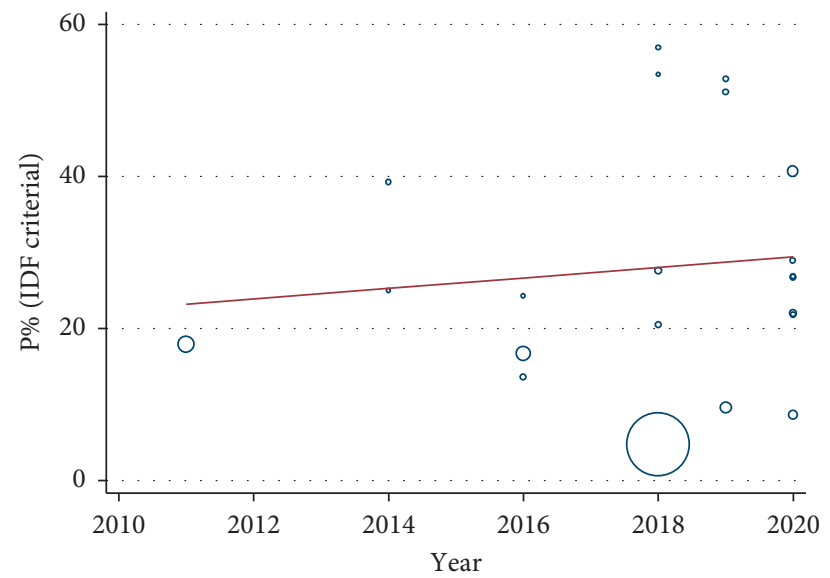

FIgURE 4: Meta-regression analysis based on published year using IDF criteria.

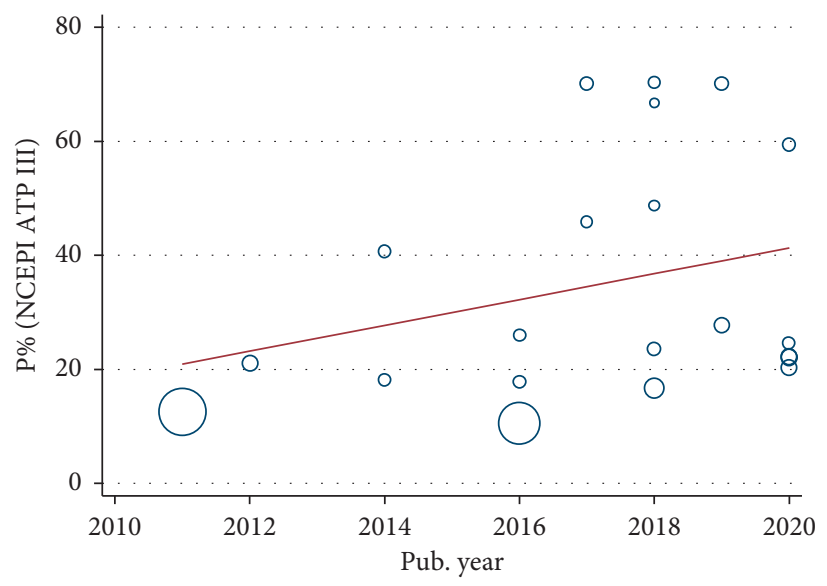

FIGURE 5: Meta-regression analysis based on published year using NCEP/ATP III criteria.

higher prevalence of MetS among the women is attributed to abdominal obesity, which is mainly due to low physical activity, higher birth rate, presence of estrogen receptors, and menopause [82]. Besides genetic variation, lifestyle might be the reason.

Low HDL-C was the most frequent individual component of MetS in the current meta-analysis which was similar to reports in Bangladesh (89\%) [65], Colombia (62.9\%) [18], and Venezuela (58.6\%) [83]. However, hypertriglyceridemia was shown the second most prominent MetS component to the contrary high blood pressure report in Bangladesh (30\%) [65]. The low concentration of HDL-C favors the accumulation of low-density lipoprotein in the blood vessels greatly due to its poor scavenging capacity of low-density 
Table 5: Pooled estimates of metabolic syndrome components.

\begin{tabular}{|c|c|c|c|c|c|c|}
\hline \multirow[b]{2}{*}{ Authors } & \multirow[b]{2}{*}{$\begin{array}{l}\text { Sample } \\
\text { size }\end{array}$} & \multicolumn{5}{|c|}{ Prevalence of metabolic syndrome components } \\
\hline & & Hypertension & Hyperglycemia & Low HDL-C & Central obesity & $\begin{array}{l}\text { Elevated } \\
\text { triglyceride }\end{array}$ \\
\hline Berhan et al. [57] & 313 & 16 & 24.9 & 46 & 13.7 & 39 \\
\hline Tachebele et al. [37] & 300 & - & 25.3 & 81.3 & 18.7 & 27.3 \\
\hline Tadewos et al. [58] & 238 & - & 35.7 & 60.9 & 37.8 & 62.2 \\
\hline Woyesa et al. [59] & 319 & 25.5 & 80 & 39.2 & 61.3 & 70.4 \\
\hline Bosho et al. [38] & 268 & 38.4 & 17.2 & 49.3 & 18.7 & 29.9 \\
\hline Hirigo et al. [39] & 185 & 9.72 & 14.59 & 70.27 & 22.7 & 44.86 \\
\hline Tran et al. [40] & 1935 & 20.65 & 19.97 & 23.32 & 18.5 & 20.59 \\
\hline Abda et al. [60] & 225 & 45 & 39 & 31 & 26 & 18 \\
\hline Tadewos et al. [61] & 270 & 28.1 & - & 47 & 40.7 & 68.1 \\
\hline Esfaye et al. [41] & 188 & 23.9 & 33.5 & 53.7 & 52.7 & 45.2 \\
\hline Biadgo et al. [42] & 159 & 55.4 & - & 32.7 & 43.4 & 56.6 \\
\hline Melak et al. [55] & 220 & 15.5 & 8.6 & 68.6 & 17.7 & 26.8 \\
\hline Ataro et al. [54] & 375 & 10.9 & 18.4 & 64.5 & 59.2 & 41.9 \\
\hline Birarra et al. [43] & 256 & 43 & - & 66.8 & 16.4 & 67.6 \\
\hline Bune et al. [46] & 422 & 56.6 & 56.4 & 30.8 & 49.1 & 42.9 \\
\hline Gebremariam et al. [47] & 1380 & 19.6 & 19.4 & 71.6 & 42.7 & 55.7 \\
\hline Gebremeskel et al. [45] & 419 & 41.3 & - & 34.4 & 59.7 & 45.1 \\
\hline Gebreyes et al. [51] & 8673 & 15.8 & 9.1 & 68.7 & 39.8 & 21.0 \\
\hline Geto et al. [56] & 450 & 23.6 & 2.4 & 41.3 & 80.2 & 19.3 \\
\hline Kerie S et al. [52] & 534 & 16.9 & 7.1 & 50.9 & 26.22 & 22.8 \\
\hline Solomon S et al. [44] & 325 & 36.3 & 32.6 & 48.6 & 19.4 & 24.0 \\
\hline Teshome T et al. [50] & 245 & 22.0 & 34.3 & 41.2 & 24.9 & 26.9 \\
\hline $\begin{array}{l}\text { Combined pooled estimates (LCI, } \\
\text { UCI) }\end{array}$ & & $\begin{array}{c}27.87(23.4 \\
32.2)\end{array}$ & $26.4(20,32.8)$ & $\begin{array}{l}51.0(42.4 \\
59.7)\end{array}$ & $\begin{array}{c}35.85(28.9 \\
42.8)\end{array}$ & $39.7(32.8,46.6)$ \\
\hline
\end{tabular}

HDL-C, high-density lipoprotein cholesterol; LCI, lower confidence interval; UCI, upper confidence interval.

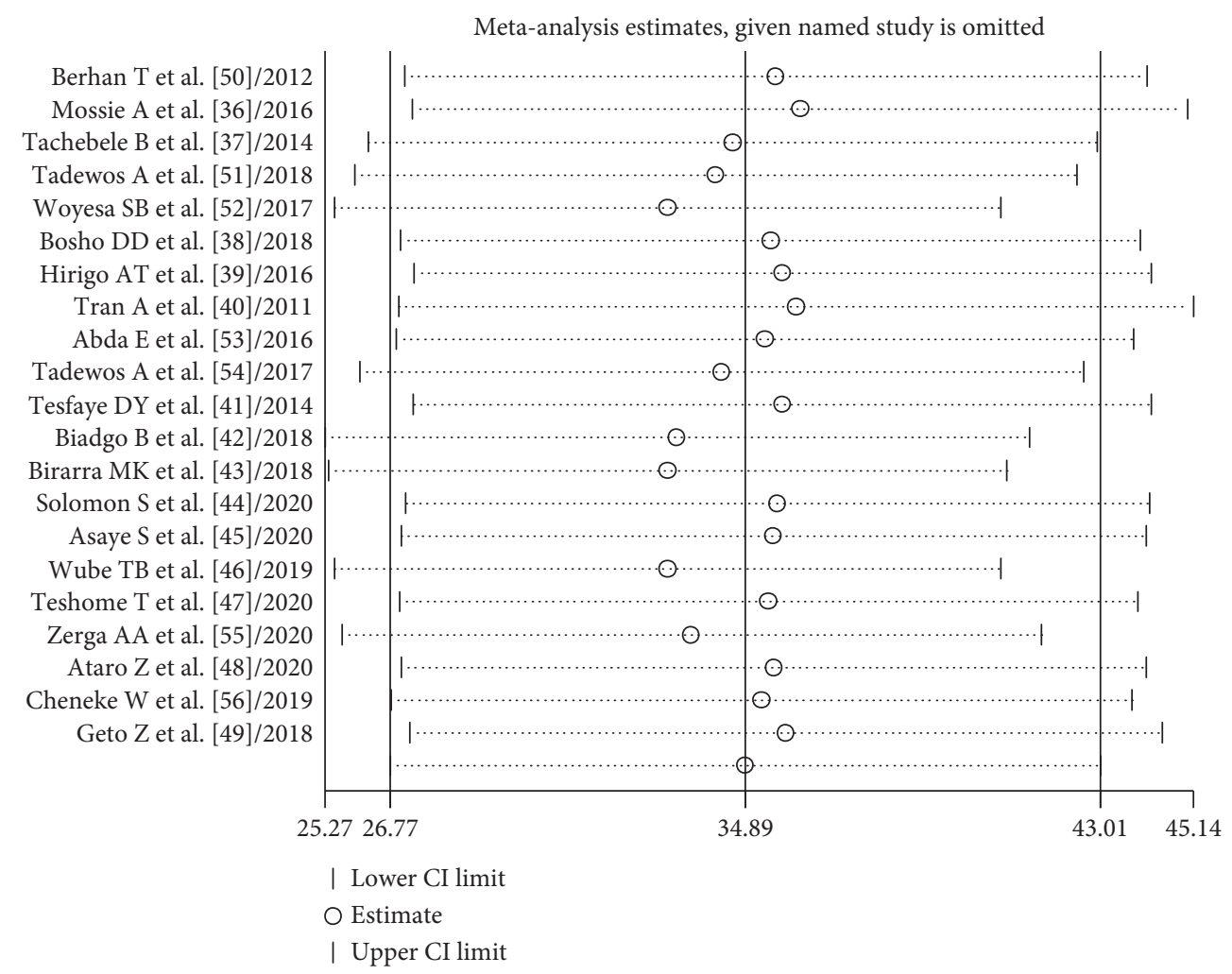

FIGURE 6: Sensitivity analysis based on NCEP/ATP III criteria. 


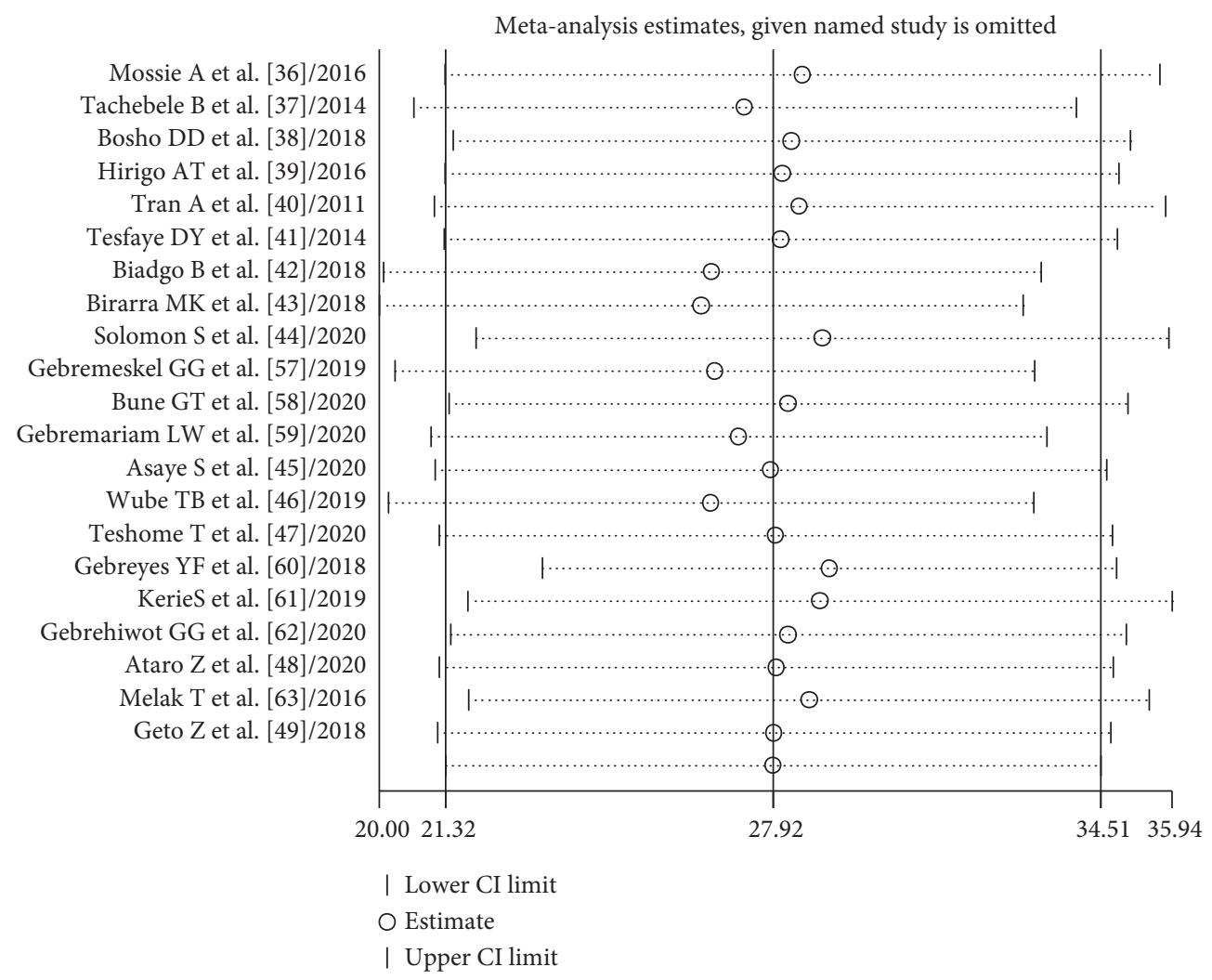

FIgURE 7: Sensitivity analysis based on IDF criteria.

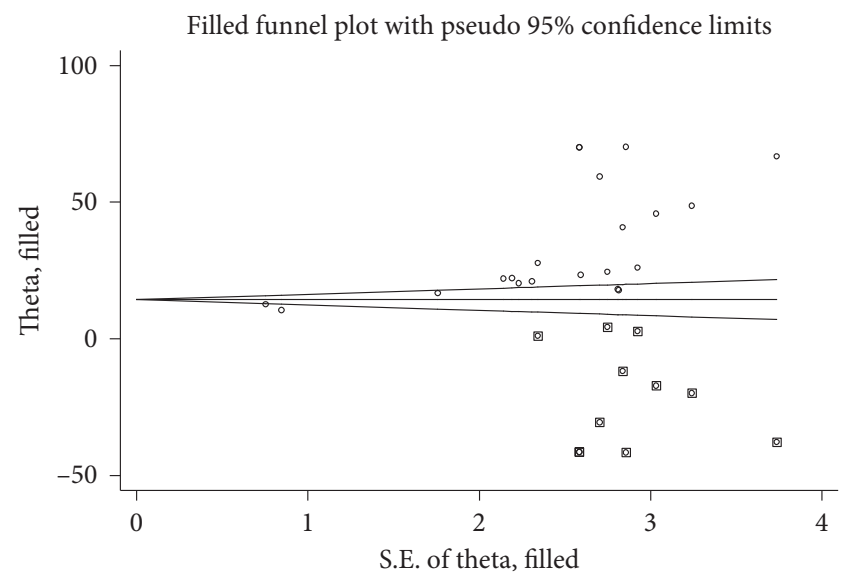

FIgUre 8: Trim and fill analysis based on NCEP/ATP III criteria.

lipoprotein from the body. The coexistence of hypertriglyceridemia and low HDL-C are risk factors for the development of CVD. It is well-known that a low concentration of the HDL-C level is a strong independent risk factor for CVD [84]. As a limitation to this review, a point needs to be noted that there is no uniformity of MetS definitions and waist circumference cutoffs points. Besides, high heterogeneity has been observed. Furthermore, there has been publication bias.

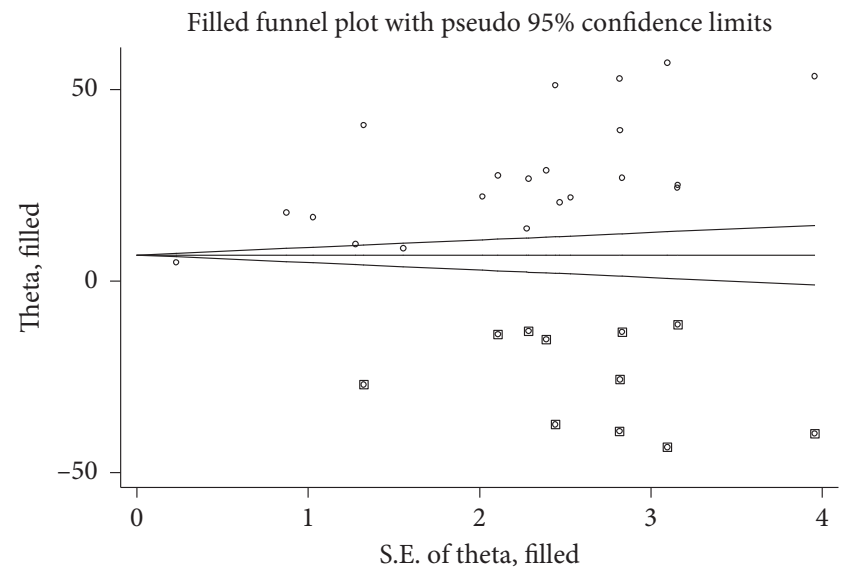

FIgURE 9: Trim and fill analysis based on IDF criteria.

\section{Conclusion}

In conclusion, our review summarizes that a large proportion of the Ethiopian population have MetS regardless of the study subjects, gender, and the definitions used. One fact is clear here. MetS is growing at an alarming rate and is high in Ethiopia. Therefore, policymakers, clinicians, and concerned stakeholders shall urge effective strategies in the control, prevention, and management of MetS. 


\section{Abbreviations}

CVD: $\quad$ Cardiovascular diseases

IDF: International Diabetes Federation

HAART: Highly active antiretroviral therapy

MetS: Metabolic syndrome

NCEP/ATP National Cholesterol Education

III: Program-Adult Treatment Panel III (NCEP/ ATP III).

\section{Data Availability}

The data used to support the findings of this study are available from the corresponding author upon request.

\section{Conflicts of Interest}

The authors declare that they have no conflicts of interest.

\section{Authors' Contributions}

S.A. was involved in conception of the research protocol, design of the study, review of the literature, data extraction, and statistical analysis. S.A. and A.E. were involved in data analysis and interpretation and drafting of the manuscript. M.M. and A.W. were involved in data interpretation and review of the manuscript. S.A., Y.T., and B.B. were involved in data extraction and quality assessment. All authors critically revised the paper, and they agreed to be accountable for all aspects of the work.

\section{References}

[1] A. S. Gami, B. J. Witt, D. E. Howard et al., "Metabolic syndrome and risk of incident cardiovascular events and death," Journal of the American College of Cardiology, vol. 49, no. 4, pp. 403-414, 2007.

[2] S. M. Grundy, H. B. Brewer, J. I. Cleeman, S. C. Smith, and C. Lenfant, "Definition of metabolic syndrome," Circulation, vol. 109, no. 3, pp. 433-438, 2004.

[3] K. G. M. Alberti, P. Zimmet, and J. Shaw, "The metabolic syndrome-a new worldwide definition," The Lancet, vol. 366, no. 9491, pp. 1059-1062, 2005.

[4] K. G. M. M. Alberti, P. Zimmet, and J. Shaw, "Metabolic syndrome-a new world-wide definition. A consensus statement from the international diabetes federation," Diabetic Medicine, vol. 23, no. 5, pp. 469-480, 2006.

[5] A. Alwan, D. R. MacLean, L. M. Riley et al., "Monitoring and surveillance of chronic non-communicable diseases: progress and capacity in high-burden countries," The Lancet, vol. 376, no. 9755, pp. 1861-1868, 2010.

[6] Group I. E. T. F. C.: International Diabetes Federation: The IDF consensus worldwide definition of the metabolic syndrome.https://http://www idf org/webdata/docs/Metabolic_ syndrome_def pdf 2005.

[7] C. Okafor, "The metabolic syndrome in Africa: current trends," Indian Journal of Endocrinology and Metabolism, vol. 16, no. 1, p. 56, 2012.

[8] A. Misra and L. Khurana, "Obesity and the metabolic syndrome in developing countries," The Journal of Clinical Endocrinology \& Metabolism, vol. 93, no. 11_supplement_1, pp. s9-s30, 2008.
[9] S. Mottillo, K. B. Filion, J. Genest et al., "The metabolic syndrome and cardiovascular risk," Journal of the American College of Cardiology, vol. 56, no. 14, pp. 1113-1132, 2010.

[10] N. Sarrafzadegan, M. Gharipour, M. Sadeghi et al., "Metabolic syndrome and the risk of ischemic stroke," Journal of Stroke and Cerebrovascular Diseases, vol. 26, no. 2, pp. 286-294, 2017.

[11] P. W. F. Wilson, R. B. D’Agostino, H. Parise, L. Sullivan, and J. B. Meigs, "Metabolic syndrome as a precursor of cardiovascular disease and type 2 diabetes mellitus," Circulation, vol. 112, no. 20, pp. 3066-3072, 2005.

[12] I. Martín-Timón, C. Sevillano-Collantes, A. Segura-Galindo, and F. J. del Cañizo-Gómez, "Type 2 diabetes and cardiovascular disease: have all risk factors the same strength?" World Journal of Diabetes, vol. 5, no. 4, p. 444, 2014.

[13] D. Dibaba, D. Braithwaite, and T. Akinyemiju, "Metabolic syndrome and the risk of breast cancer and subtypes by race, menopause and BMI," Cancers, vol. 10, no. 9, p. 299, 2018.

[14] K. Ehala-Aleksejev and P. MJPo, "The effect of metabolic syndrome on male reproductive health: a cross-sectional study in a group of fertile men and male partners of infertile couples," World Journal of Diabetes, vol. 13, no. 3, Article ID e0194395, 2018.

[15] M. Hamaguchi, T. Kojima, N. Takeda et al., "The metabolic syndrome as a predictor of nonalcoholic fatty liver disease," Annals of Internal Medicine, vol. 143, no. 10, pp. 722-728, 2005.

[16] P. T. Katzmarzyk, T. S. Church, I. Janssen, R. Ross, and S. N. Blair, "Metabolic syndrome, obesity, and mortality: impact of cardiorespiratory fitness," Diabetes Care, vol. 28, no. 2, pp. 391-397, 2005.

[17] M.-A. Cornier, D. Dabelea, T. L. Hernandez et al., "The metabolic syndrome," Endocrine Reviews, vol. 29, no. 7, pp. 777-822, 2008.

[18] F. Márquez-Sandoval, G. Macedo-Ojeda, D. ViramontesHörner, J. Fernández Ballart, J. Salas Salvadó, and B. Vizmanos, "The prevalence of metabolic syndrome in Latin America: a systematic review," Public Health Nutrition, vol. 14, no. 10, pp. 1702-1713, 2011.

[19] V. Estrada, M. T. Martínez-Larrad, J. L. González-Sánchez et al., "Lipodystrophy and metabolic syndrome in HIV-infected patients treated with antiretroviral therapy," Metabolism, vol. 55, no. 7, pp. 940-945, 2006.

[20] O. O. Todowede, S. Z. Mianda, and B. Sartorius, "Prevalence of metabolic syndrome among HIV-positive and HIV-negative populations in sub-Saharan Africa-a systematic review and meta-analysis," Systematic Reviews, vol. 8, no. 1, p. 4, 2019.

[21] S. Abhayaratna, N. Somaundaram, and H. Rajapakse, "Prevalence of the metabolic syndrome among patients with type 2 diabetes," Sri Lanka Journal of Diabetes Endocrinology and Metabolism, vol. 5, no. 2, 2015.

[22] I. Papadakis, G. Vrentzos, M. Zeniodi, and E. Ganotakis, "Pp.33.01: prevalence of metabolic syndrome in patients with essential hypertension in Greece," Journal of Hypertension, vol. 33, p. e429, 2015.

[23] C. Obirikorang, L. Quaye, J. Osei-Yeboah, E. Odame, and I. Asare, "Prevalence of metabolic syndrome among HIVinfected patients in Ghana: a cross-sectional study," Nigerian Medical Journal, vol. 57, no. 2, p. 86, 2016.

[24] M. P. Canale, S. Manca di Villahermosa, G. Martino et al., "Obesity-related metabolic syndrome: mechanisms of sympathetic overactivity," vol. 2013, 13 pages, 2013, https://www. hindawi.com/journals/ije/. 
[25] C. Alvarez, R. Salazar, J. Galindez et al., "Metabolic syndrome in HIV-infected patients receiving antiretroviral therapy in latin America," Brazilian Journal of Infectious Diseases, vol. 14, no. 3, pp. 256-263, 2010.

[26] A.-J. Pyykkönen, K. Räikkönen, T. Tuomi, J. G. Eriksson, L. Groop, and B. Isomaa, "Stressful life events and the metabolic syndrome: the prevalence, prediction and prevention of diabetes (PPP)-botnia study," Diabetes Care, vol. 33, no. 2, pp. 378-384, 2010.

[27] M. Das, S. Pal, and A. Ghosh, "Family history of type 2 diabetes and prevalence of metabolic syndrome in adult Asian Indians," Journal of Cardiovascular Disease Research, vol. 3, no. 2, pp. 104-108, 2012.

[28] E. S. Ford, H. W. Kohl, A. H. Mokdad, and U. A. Ajani, "Sedentary behavior, physical activity, and the metabolic syndrome among U.S. Adults," Obesity Research, vol. 13, no. 3, pp. 608-614, 2005.

[29] S. P. Iqbal, A. Ramadas, Q. K. Fatt, H. L. Shin, W. Y. Onn, and K. Kajpo, "Relationship of sociodemographic and lifestyle factors and diet habits with metabolic syndrome (MetS) among three ethnic groups of the Malaysian population," PLoS One, vol. 15, no. 3, Article ID e0224054, 2020.

[30] A. A. Motala, J.-C. Mbanya, and K. L. Ramaiya, "Metabolic syndrome in sub-Saharan Africa," Ethnicity \& Disease, vol. 19, no. Suppl 2, pp. S2-S8, 2009.

[31] F. Young, J. A. Critchley, L. K. Johnstone, and N. C. Unwin, "A review of co-morbidity between infectious and chronic disease in Sub Saharan Africa: TB and diabetes mellitus, HIV and metabolic syndrome, and the impact of globalization," Globalization and Health, vol. 5, no. 1, p. 9, 2009.

[32] O. Cijijoe, "Metabolism: the metabolic syndrome in Africa," Current Trends, vol. 16, no. 1, p. 56, 2012.

[33] D. Moher, A. Liberati, J. Tetzlaff, D. G. Altman, and P. Group, "Preferred reporting items for systematic reviews and metaanalyses: the PRISMA statement," PLoS Medicine, vol. 6, no. 7, Article ID e1000097, 2009.

[34] A. Rezaianzadeh, S.-M. Namayandeh, and S. S. Mjijopm, "National cholesterol education program adult treatment panel III versus international diabetic federation definition of metabolic syndrome, which one is associated with diabetes mellitus and coronary artery disease?" International Diabetes Federation, vol. 3, no. 8, p. 552, 2012.

[35] Z. Munn, S. Moola, D. Riitano, and K. Lisy, "The development of a critical appraisal tool for use in systematic reviews addressing questions of prevalence," International Journal of Health Policy and Management, vol. 3, no. 3, p. 123, 2014.

[36] A. Mossie and Y. Mezgebu, "Prevalence of metabolic syndrome and its components in jimma town, South west Ethiopia," Valley International Journal, vol. 3, no. 3, 2016.

[37] B. Tachebele, M. Abebe, Z. Addis, and M. NJBcd, "Metabolic syndrome among hypertensive patients at University of Gondar Hospital, North West Ethiopia: a cross sectional study," vol. 14, no. 1, p. 177, 2014, https://bmccardiovascdisord.biomedcentral. $\mathrm{com} /$.

[38] D. D. Bosho, L. Dube, T. A. Mega, D. A. Adare, M. G. Tesfaye, and T. C. J. D. Eshetie, "Syndrome m: prevalence and predictors of metabolic syndrome among people living with human immunodeficiency virus (PLWHIV)," vol. 10, no. 1, p. 10, 2018, https://bmccardiovascdisord.biomedcentral.com/.

[39] A. T. Hirigo and T. Dyjbrn, "Influences of gender in metabolic syndrome and its components among people living with HIV virus using antiretroviral treatment in Hawassa," Southern Ethiopia, vol. 9, no. 1, p. 145, 2016.
[40] A. Tran, B. Gelaye, B. Girma et al., "Prevalence of metabolic syndrome among working adults in ethiopia," 2011.

[41] D. Y. Tesfaye, S. Kinde, G. Medhin et al., "Burden of metabolic syndrome among HIV-infected patients in Southern Ethiopia," Diabetes \& Metabolic Syndrome: Clinical Research \& Reviews, vol. 8, no. 2, pp. 102-107, 2014.

[42] B. Biadgo, T. Melak, S. Ambachew et al., "The prevalence of metabolic syndrome and its components among type 2 diabetes mellitus patients at a tertiary hospital, northwest Ethiopia," Ethiopian Journal of Health Sciences, vol. 28, no. 5, 2018.

[43] M. K. Birarra and G. Dajbcd, "Metabolic syndrome among type 2 diabetic patients in Ethiopia: a cross-sectional study," PLoS One, vol. 18, no. 1, p. 149, 2018.

[44] S. Solomon and M. WJBcd, "Disease burden and associated risk factors for metabolic syndrome among adults in Ethiopia," Southern-Ethiopia Journal, vol. 19, no. 1, p. 236, 2019.

[45] G. G. Gebremeskel, K. K. Berhe, D. S. Belay et al., "Magnitude of metabolic syndrome and its associated factors among patients with type 2 diabetes mellitus in ayder comprehensive specialized hospital, Tigray, Ethiopia: a cross sectional study," Journal of South West Ethiopia, vol. 12, no. 1, p. 603, 2019.

[46] G. T. Bune, A. W. Yalew, and A. J. Kumie, "The extents of metabolic syndrome among Antiretroviral Therapy exposed and ART naïve adult HIV patients in the Gedeo-zone, Southern-Ethiopia: a comparative cross-sectional study," Journal of South West Ethiopia, vol. 78, pp. 1-10, 2020.

[47] L. W. Gebremariam, C. Chiang, H. Yatsuya et al., "Noncommunicable disease risk factor profile among public employees in a regional city in northern Ethiopia," Journal of Northern Ethiopia, vol. 8, no. 1, pp. 1-11, 2018.

[48] S. Asaye, S. Bekele, D. Tolessa, W. Cheneke, and M. S. C. Research, "Metabolic syndrome and associated factors among psychiatric patients in jimma university specialized hospital, South west Ethiopia," Diabetes \& Metabolic Syndrome: Clinical Research \& Reviews, vol. 12, no. 5, pp. 753-760, 2018.

[49] T. B. Wube, M. M. Nuru, and A. T. J. D. Anbese, "Metabolic Syndrome, Targets O, Therapy: a comparative prevalence of metabolic syndrome among type 2 diabetes mellitus patients in Hawassa university comprehensive specialized Hospital using four different diagnostic criteria," Medical Journal of Shree Birendra Hospital, vol. 12, p. 1877, 2019.

[50] T. Teshome, D. H. Kassa, and A. Tadewos Hirigo, "Metabolic syndrome, targets $\mathrm{O}$, therapy: prevalence and associated factors of metabolic syndrome among patients with severe mental illness at hawassa," Southern-Ethiopia Journal, vol. 13, p. 569, 2020.

[51] Y. F. Gebreyes, D. Y. Goshu, T. K. Geletew et al., "Prevalence of high bloodpressure, hyperglycemia, dyslipidemia, metabolic syndrome and their determinants in Ethiopia: evidences from the National NCDs STEPS Survey, 2015," PLoS One, vol. 13, no. 5, Article ID e0194819, 2018.

[52] S. Kerie, M. Menberu, and G. Mjpo, "Metabolic syndrome among residents of Mizan-Aman town, South West Ethiopia, 2017: A Cross Sectional Study," PLoS One, vol. 14, no. 1, Article ID e0210969, 2019.

[53] G. G. Gebrehiwot, T. Belachew, K. Mehari, and D. Tamiru, "Magnitude of metabolic syndrome and its components among adult residents of mekelle city, northern ethiopia, community-based cross-sectional study," 2020.

[54] Z. Ataro, A. WjeajoH, and B. Sciences, "Metabolic syndrome and associated factors among adult HIV positive people on antiretroviral therapy in Jugal hospital, Harar, Eastern 
Ethiopia," Eastern-Ethiopia Journal, vol. 4, no. 1, pp. 13-24, 2020.

[55] T. D. S. Melak, H. W. Baynes, D. Asmelash, B. Biadgo, and A. S. Abebe, "Prevalence of metabolic syndrome and associated factors among academic staffs of university of gondar, northwest ethiopia," Master Thesis, University of Gondar, Gondar, Ethiopia, 2016.

[56] S. D. Geto Zeleke and T. Mariam Maria, "Assessment of cardiometabolic risks andassociated factors among ethiopian publichealth institute staff members," Master Thesis, Addis Abeba University, Addis Abeba, Ethiopia, 2018.

[57] T. Berhane, A. Yami, F. Alemseged et al., "Prevalence of lipodystrophy and metabolic syndrome among HIV positive individuals on Highly Active Anti-Retroviral treatment in Jimma, South West Ethiopia," Southern Ethiopia, vol. 13, no. 1, 2012.

[58] A. Tadewos, T. Egeno, and A. Ajbcd, "Risk factors of metabolic syndrome among hypertensive patients at Hawassa University Comprehensive Specialized Hospital," Southern Ethiopia, vol. 17, no. 1, p. 218, 2017.

[59] S. B. Woyesa, A. T. Hirigo, and W. Tbjbed, "Hyperuricemia and metabolic syndrome in type 2 diabetes mellitus patients at Hawassa university comprehensive specialized hospital," Journal of South West Ethiopia, vol. 17, no. 1, p. 76, 2017.

[60] E. Abda, L. Hamza, F. Tessema, and W. J. D. Cheneke, "Metabolic syndrome, targets o, therapy: metabolic syndrome and associated factors among outpatients of Jimma University Teaching Hospital," Journal of South West Ethiopia, vol. 9, p. 47, 2016.

[61] A. Tadewos, H. Ambachew, and D. J. H. S. J. Assegu, "Pattern of metabolic syndrome in relation to gender among type-II DM patients in hawassa university comprehensive specialized hospital, hawassa, southern Ethiopia," Journal of South West Ethiopia, vol. 11, no. 3, 2017.

[62] A. A. Zerga, A. M. Bezabih, A. K. Adhanu, and S. E. J. D. Tadesse, "Metabolic syndrome, targets O, therapy: obesity indices for identifying metabolic syndrome among type two diabetes patients attending their follow-up in dessie referral hospital," North East Ethiopia, vol. 13, p. 1297, 2020.

[63] W. Cheneke and B. J. I. Sufa, "Metabolic syndrome among women using hormonal contraceptives IN harar town, eastern Ethiopia," Journal of Eastern Ethiopia, vol. 7, no. 10, pp. 400-406, 2019.

[64] F. de Carvalho Vidigal, J. Bressan, N. Babio, and J. SalasSalvadó, "Prevalence of metabolic syndrome in Brazilian adults: a systematic review," BMC Public Health, vol. 13, no. 1, p. 1198, 2013.

[65] M. Z. I. Chowdhury, A. M. Anik, Z. Farhana et al., "Prevalence of metabolic syndrome in Bangladesh: a systematic review and meta-analysis of the studies," BMC Public Health, vol. 18, no. 1, p. 308, 2018

[66] S. Dalvand, S. H. Niksima, R Meshkani et al., "Prevalence of metabolic syndrome among iranian population: a systematic review and meta-analysis," Iranian Journal of Public Health, vol. 46, no. 4, p. 456, 2017.

[67] A. El-Zayadi, O. Selim, H. Hamdy, H. Dabbous, A. Ahdy, and S. Moniem, "Association of chronic hepatitis C infection and diabetes mellitus," Tropical Gastroenterology: Official Journal of the Digestive Diseases Foundation, vol. 19, no. 4, pp. 141-144, 1998.

[68] R. Ofori-Asenso, A. A. Agyeman, and A. Laar, "Metabolic syndrome in apparently "healthy" Ghanaian adults: a systematic review and meta-analysis," International Journal of Chronic Diseases, vol. 2017, 2017.
[69] P. Ranasinghe, Y. Mathangasinghe, R. Jayawardena, A. Hills, and A. Misra, "Prevalence and trends of metabolic syndrome among adults in the asia-pacific region: a systematic review," BMC Public Health, vol. 17, no. 1, p. 101, 2017.

[70] A. H. el Bilbeisi, S. Shab-Bidar, D. Jackson, and K. Djafarian, "The prevalence of metabolic syndrome and its related factors among adults in Palestine: a meta-analysis," Ethiopian Journal of Health Sciences, vol. 27, no. 1, pp. 77-84, 2017.

[71] V. G. Athyros, E. S. Ganotakis, K. Tziomalos et al., "Comparison of four definitions of the metabolic syndrome in a Greek (Mediterranean) population," Current Medical Research and Opinion, vol. 26, no. 3, pp. 713-719, 2010.

[72] B. R. Maharjan, S. Bhandary, I. Shrestha, L. Sunuwar, and S. Shrestha, "Prevalence of metabolic syndrome in local population of patan," Medical Journal of Shree Birendra Hospital, vol. 11, no. 1, pp. 27-31, 2012.

[73] M. Kubota, M. Yoneda, N Maeda et al., "Westernization of lifestyle affects quantitative and qualitative changes in adiponectin," BMC Public Health, vol. 16, no. 1, p. 83, 2017.

[74] U. J. Lopuszanska, K. Skorzynska-Dziduszko, K. Lupa-Zatwarnicka, M.-S. MJAoA, and E. Medicine, "Mental illness and metabolic syndrome-a literature review," BMC Public Health, vol. 21, no. 4, 2014.

[75] M. Bahrami, M. Cheraghpour, S. Jafarirad, P. Alavinejad, B. J. N. Cheraghian, and F. Science, "The role of melatonin supplement in metabolic syndrome," Journal of Endocrinology and Metabolism, vol. 31, 2019.

[76] M. Desai, J. Babu, and M. G. J. A Ross, "Integrative, Physiology C: programmed metabolic syndrome: prenatal undernutrition and postweaning overnutrition," BMC Public Health, vol. 293, no. 6, pp. R2306-R2314, 2007.

[77] G. Corona, E. Mannucci, L. Petrone et al., "ENDOCRINOLOGY: a comparison of NCEP-ATPIII and IDF metabolic syndrome definitions with relation to metabolic syndromeassociated sexual dysfunction," Journal of Endocrinology and Metabolism, vol. 4, no. 3, pp. 789-796, 2007.

[78] S. M. Grundy, J. I. Cleeman, S. R. Daniels et al., "Diagnosis and management of the metabolic syndrome: an American heart association/national heart, lung, and blood Institute scientific statement," Circulation, vol. 112, no. 17, pp. 2735-2752, 2005.

[79] A. Saiki, T. Oyama, K. Endo et al., "Preheparin serum lipoprotein lipase mass might be a biomarker of metabolic syndrome," Journal of Endocrinology and Metabolism, vol. 76, no. 1, pp. 93-101, 2007.

[80] F. Sayehmiri, "Metabolic syndrome prevalence in Iran: a systematic review and meta-analysis," Journal of Endocrinology and Metabolism, vol. 36, 2007.

[81] H. A. Sliem, S. Ahmed, N. Nemr, and I. El-Sherif, "Metabolic syndrome in the Middle East," Indian Journal of Endocrinology and Metabolism, vol. 16, no. 1, p. 67, 2012.

[82] R. Bentley-Lewis, K. Koruda, and E. W. J. N. C. P. E. Seely, "Metabolism: the metabolic syndrome in women," Journal of Endocrinology and Metabolism, vol. 3, no. 10, pp. 696-704, 2007.

[83] I. Brajkovich, J. P. González-Rivas, E. Ugel, A. Rísquez, and R. Nieto-Martínez, "Prevalence of metabolic syndrome in three regions in Venezuela: the VEMSOLS study," International Journal of Cardiovascular Sciences, vol. 81, 2018.

[84] M. Adiels, S.-O. Olofsson, and M.-R. Taskinen, "Thrombosis,, biology v: Overproduction of very low-density lipoproteins is the hallmark of the dyslipidemia in the metabolic syndrome," Journal of Endocrinology and Metabolism, vol. 28, no. 7, pp. 1225-1236, 2008. 